УДК 615.012.1:547.789.1

\title{
ВИКОРИСТАННЯ СУЧАСНИХ ІНФОРМАЦИЙНИХ ТЕХНОЛОГІЙ ДЛЯ УДОСКОНАЛЕННЯ САМОСТІЙНОЇ РОБОТИ СТУДЕНТІВ
}

\author{
Л. Д. Чулак, А. О. Бас, В. Г. Шутурмінський, В. В. Корчемний \\ Одеський національниймедичний університет
}

\section{USE OF CONTEMPORARY INFORMATION TEXNOLOGIES FOR THE IMPROVEMENT OF THE INDEPENDENT WORK OF STUDENTS}

\author{
L. D. Chulak, A. O. Bas , V. H. Shuturminskyi, V. V. Korchemnyi \\ Odessa National Medical University
}

\begin{abstract}
У роботі представлений досвід викладення матеріалу з курсу ортопедичної стоматології на сайті зі застосуванням сучасних Інтернет-технологій.

В результаті обговорення матеріалу автори пропонують цей сучасний метод як основний засіб для самостійної роботи студентів.
\end{abstract}

The work presents the experience of the account of the material on the course of prosthodontics on the web-site with the application of contemporary Internet- technologies.

As a result of the material consideration the authors propose this contemporary method as basic means for the independent work of students.

Вступ. Складовою частиною реалізації стратегії інтеграції України до Європейського Союзу та підвищення конкурентоспроможності наших фахівців $\mathrm{\epsilon}$ модернізація системи вітчизняної освіти [1].

Відомо, що важливими недоліками організації навчально-виховного процесуу вищій школі в даний час $\epsilon$ переважання репродуктивних форм навчання, методів пасивного засвоєння над методами активної роботи [2]. Тому підготовка освічених і кваліфікованих кадрів для сучасного ринку праці вимагає серйозних змін у підходах до навчання, до структури $\mathrm{i}$ змісту навчального процесу [3].

При вирішенні таких завдань важливого значення набуває організація самостійної роботи студентів, на яку, згідно 3 навчальними планами, відводиться близько $1 / 3$ всього навчального часу [4].

За рахунок недостатнього фінансування навчального процесу в медичних вузах України якісно, на європейському рівні проводити навчання студентів не можливо. Студенти повинні бути забезпечені усіма розхідними матеріалами, необхідними інструментами, муляжами та тренінговим обладнанням, достатньою кількістю сучасної навчальної літератури. Всього цього вкрай недостатньо i, на жаль, у найближчий час ситуація навряд чи зміниться на краще.

Все це обумовлює вдосконалення існуючих та пошук нових навчальних технологій і методичних прийомів у навчальному процесі, які дозволять майбутнім фахівцям набути глибоких професійних знань, навчитися орієнтуватись у великому інформаційному потоці, оволодіти новітніми технологіями та привчитися постійно поновлювати свої знання [5].

Тому для покращення якості навчального процесу ми поставили для себе за мету - вдосконалити якість навчального процесу 3 ортопедичної стоматології за рахунок винесення частини навчального матеріалу в мережу Internet.

Основна частина. На кафедрі ортопедичної стоматології Одеського національного медичного університету було створено сайт (http:// www.ortstom.odmu.edu.ua), направлений на вирішення таких задач:

1. Інформування студентів про хід навчального процесу та вимоги кафедри до підготовки.

2. Методичне забезпечення самостійної роботи студентів.

3. Наочність та інтерактивність поданого матеріалу.

4. Знайомство з новітніми технологіями, які ще не набули достатнього освітлення в навчальній програмі.

5. Винесення основного часу з підготовки до ліцензованого іспиту “Крок 2" на самостійну роботу з можливістю самоконтролю.

6. Можливість одержання студентами додаткової індивідуальної консультації під час самопідготовки.

() Л. Д. Чулак, А. О. Бас, В. Г. Шутурмінський, В. В. Корчемний 
7. Можливість обміну набутою інформацією та іiі обговорення під час самостійної роботи.

8. Стимулювання активної роботи з пошуку інформації для її осмислення та вільного володіння нею.

9. Використання змагального компонента для підвищення мотивації самостійної роботи студентів.

10. Поновлювання знань випускників.

3 метою інформування студентів про хід навчального процесу та вимог кафедри до підготовки сайт кафедри має розділ “Навчальна робота". Цей розділ містить таку інформацію: 1) розклад занять; 2) розподіл груп студентів по викладачах; 3) календарно-тематичні плани лекцій та практичних занять; 4) перелік обов' язкових практичних навичок; 5) розклад рубіжних контролів, заліків, дифзаліків, іспитів та модульних контролів; 6) питання та завдання до дифзаліків, іспитів та модульних контролів; 7) критерії оцінки знань. Таким чиному студентів відпадають питання про тему наступного заняття, вимог кафедри до підготовки до дифзаліків, іспитів та модульних контролів. Студенти вже до першого заняття в семестрі інформовані, у якій аудиторії проводяться заняття, яким викладачем та яка тема заняття. Це особливо важливо в умовах кредитно-модульної системи навчання, при якій студенти повинні отримати оцінку вже на першому ж занятті.

Ознайомившись 3 темою наступного заняття та вимогами до підготовки, студенти можуть перейти у наступний розділ сайту “Методична робота”. Цей розділ містить методичні розробки до практичних занять, у яких подано наступну інформацію: стисло зміст теми, питання, тести, ситуаційні задачі, що виносяться до розгляду на занятті. Для зручності використання матеріали сайту представлено російською, українською та англійською мовами.

Якщо під час підготовки у студентів виникають додаткові питання, вони можуть скористатися пошуковою системою сайту.

Для ілюстрації поданого матеріалу на сайті представлено розділи фото- та відеоматеріалів, які систематизовано за розділами ортопедичної стоматології. Ці розділи постійно поповнюються. Користувачі сайту можуть добавляти на ці сторінки сайту свої матеріали та обговорювати їх 3 колегами.

Найбільш важливі та складні для засвоювання теми представлено у вигляді мультимедійних лекцій, які користувачі сайту можуть переглядати в режимі online. У теперішній час ведеться робота зі створення iнтерактивних лекцій (http://www.ortstom.odmu.edu.ua/ ru/metodicheskaja-rabota/lektsii/3-kurs-6-semestr/90tehnologichni-osnovi-vigotovlennja-bjugelnih-protezivdubljuvannja-modelej-litvo-karkasiv).

Поданий у лекції текстовий матеріал має голосове супроводження та наглядно ілюстровано. Після матеріалу лекції подано питання за ії змістом, за якими студенти можуть самостійно перевірити якість засвоєння матеріалу. У випадку неправильної відповідіє підказка, що відкриває слайд з правильною відповіддю та поясненням (рис. 1).

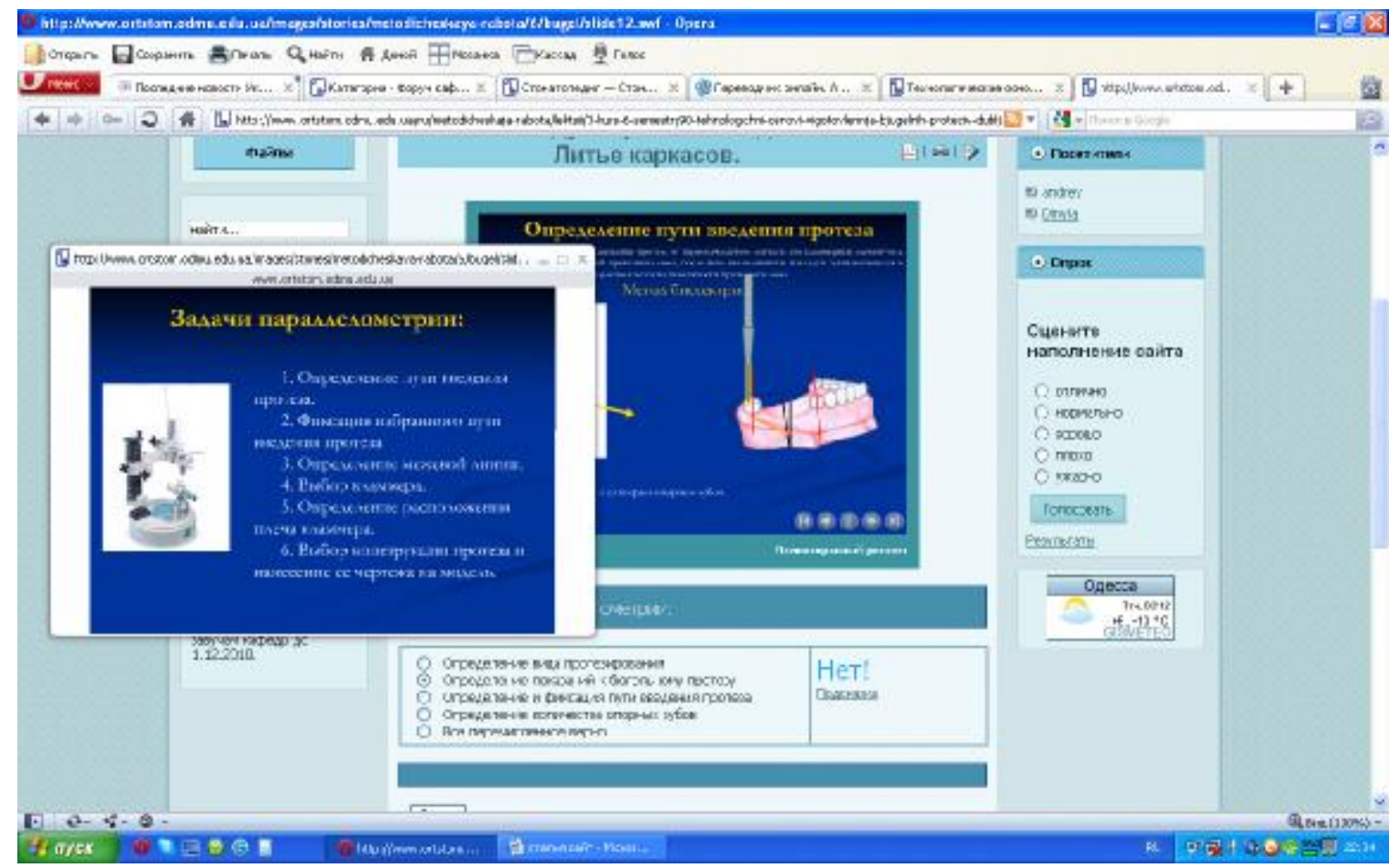

Puc. 1. Інтерактивне засвоєння лекції за запитаннями. 
На сайті також розміщено мультимедійні лекції, що освітлюють виготовлення зубних протезів за найсучаснішими технологіями, які ще не набули достатнього висвітлення в навчальній програмі та підручниках, такі як: безметалева кераміка, безакрилові знімні протези, протезування на імплантатах та ін. Ці матеріали ілюстровані роботами співробітників кафедри. Ці матеріали $є$ цікавими як для студентів, так і для випускників, що вже ведуть самостійну практику.

Для представлення на сайті готується сторінка практичних навичок. На цій сторінці буде не тільки текстове описання алгоритму виконання стоматологічних маніпуляцій, а й відеоролики з демонстрацією його виконання з метою наочності.

Для більш детального вивчення матеріалу студенти можуть скористатися електронною бібліотекою кафедри як на базах кафедри, так і в науковій бібліотеці університету. Інформація про наявну літературу також відображена на сайті.

Важливою ланкою підготовки студентів $є$ робота 3 базою тестів "Крок 2". Проте на сьогодні ця база налічує вже декілька тисяч питань і обговорювання ïx усіх під час практичних занять $€$ нераціональним використанням навчального часу. Тому сайт кафедри має розділ “Крок 2". Цей розділ містить банк тестових питань, які систематизовано за розділами та роками появи в відкритому банку тестів. Студенти мають можливість самостійного on-line тестування. Цей розділ сайту забезпечений сервером статистики, який надає користувачу інформацію про результати його тестування по кожному розділу тестових завдань. Надана інформація дозволяє студентам визначити розділи тестів, за якими вони мають найгірші результати, та приділити більше уваги саме цим розділам. Для створення серед студентів здорової робочої конкуренції і підвищення мотивації до самопідготовки сервер статистики має “Алею слави”, на якій відображено рейтинг користувачів програми тестування.

Викладачам кафедри сервер статистики надає інформацію про тестові завдання, які викликають найбільші складнощі у студентів. Саме цим питанням і приділяється увага на практичних заняттях.

Для більш доступного подання навчального матеріалу на сайті кафедри створено "Стоматопедію” (від др.-грец. $\sigma \tau о \mu \alpha \tau о \varsigma-$ рот + грец. $\pi \alpha 1 \delta \varepsilon i \alpha-$ виховання, навчання) - це спроба створити повну, загальнодоступну, багатомовну енциклопедію знань, прямо або побічно пов' язаних із стоматологією. "Стоматопедію" побудовано за технологією "Вікі" (у перекладі з гавайської wiki - wiki - швидко), ця тех- нологія уперше була використана у 1995 році Уордом Каннінгемом, розробником першої вікі-системи [6].

Переваги такої системи - у створенні звичайних джерел інформації бере участь обмежене число авторів. "Стоматопедію" може створювати будь-який відвідувач. Розширення круга авторів дає можливість професійно описувати різні галузі знань.

Недоліки такої системи - для написання достовірних і грамотних статей потрібні певні знання і навички. Автори, особливо початківці, можуть допускати безліч помилок і неточностей у своїх роботах. Шляхом вирішення проблеми $€$ те, що кожен користувач може обговорити будь-яку статтю з іншими користувачами або відредагувати недостовірну інформацію. Адміністратори (у нашому випадку викладачі кафедри) також можуть редагувати будь-яку статтю та повернути іï більш ранню та вдалішу версії.

Будь-яка інформація може посилатися на інші статті або категорії.

Переваги: практично усі наукові публікації обмежені у своєму об'ємі, а тому автори не звертають уваги на деталі, вважаючи, що читач вже має базові знання в тій або іншій сфері знань, медицині зокрема. Без цих знань неможливо в повному об'ємі зрозуміти усю інформацію, яку хотів донести автор своєму читачеві. "Стоматопедія" практично необмежена у своїх розмірах, а тому автори енциклопедії можуть явно вказувати на ті статті і категорії, без вивчення яких важко зрозуміти увесь сенс цієї статті. Будьяка інформація може бути об'єднана в одну або декілька категорій.

Переваги:

- систематизація і структуризація інформації сприяє iї розумінню і засвоєнню;

- усі зміни з'являються відразу після їх внесення;

- на відміну від паперового навчального посібника, коли з моменту написання книги автором до того часу, коли вона потрапляє до читача, проходять місяці, а іноді і роки, на сайтах подібних “Стоматопедії” нерідкі випадки, коли інформація оновлюється через декілька хвилин після самої події.

Недолік: моментальна публікація допускає можливість попадання в енциклопедію недостовірної інформації.

Як вже зрозуміло $з$ вищенаведеного, створюють "Стоматопедію” переважно студенти. Для стимулювання творчої діяльності у робочій програмі кафедри передбачені заохочувальні бали для студентів кредитно-модульної системи навчання, які активно беруть участь у створенні “Стоматопедії”. Викладачі кафедри, перевіряючи якість статей, створених сту- 
дентами, для нарахування заохочувальних балів, одночасно мають змогу їх редагувати, що підвищує якість “Стоматопедіи”.

Проте зрозуміло, що робота сайту та створення “Стоматопедіï” тільки розпочато. Тому у студентів під час самостійної роботи може виникати велика кількість питань. Відповіді на ці питання також можна отримати практично відразу на форумі, що працює на сайті. Кваліфіковані відповіді на питання надають викладачі кафедри, які у свій вільний час присутні на сайті.

Представлена на сайті інформація також $є$ корисною для наших випускників. Вони можуть оновити свої знання, дізнатися про новітні технології, що прийшли в стоматологію вже після закінчення ними університету. На сайті є розділ новин, який освітлює стоматологічні новини з інших сайтів. На сайті розміщено матеріали для підготовки до ліцензованого іспиту “Крок 3”. Крім того, випускники можуть скористатися форумом для отримання консультацій для своєї лікарської практики не виходячи з робочого кабінету.

Про інтерес користувачів до сайту свідчить збільшення числа зареєстрованих осіб. Приємно, що серед зареєстрованих є студенти інших університетів України.

Для оцінки проведеної роботи та врахування недоліків в подальшій роботі нами проводяться опитування, результати яких представлено в таблиці 1.

Таблиця 1. Результати оцінювання користувачами Internet якості сайту, \% осіб

\begin{tabular}{|c|c|c|c|c|}
\hline \multicolumn{5}{|c|}{ “Оцінка наповнення сайту”, \% } \\
\hline Відмінно & Добре & Нормально & Погано & Жахливо \\
\hline 50,0 & - & 33,3 & 16,7 & - \\
\hline \multicolumn{6}{|c|}{ "Чи використовуєте Ви матеріали сайту для підготовки до занять”, \% } \\
\hline Так & Не часто & Незручно & Ні & \\
\hline 73,3 & 6,7 & - & 20,0 & \\
\hline
\end{tabular}

Висновок. Таким чином, на кафедрі ортопедичної стоматології ОНМедУ (завідувач кафедри проф. Л. Д. Чулак) створено сайт, який виконує усі поставлені перед ним задачі. Проте оцінювати результати його роботи поки що зарано.

Створення подібного Інтернет-ресурсу - це цілком ентузіазм викладачів кафедри. На наш погляд, було б доцільно створення комісії на всеукраїнському рівні для визначення переліку необхідних інтерактивних навчально-методичних матеріалів, їх збору та рецен-

\section{Література}

1. Ковальчук Л. Є. Удосконалення самостійної роботи студентів - необхідна умова реалізації ідей Болонського процесу / Л. Є. Ковальчук, В. І. Шутак, П. М. Телюк // Галицький лікарський вісник. -2008. - Т. 15, № 1. - С. 79-80.

2. Грубінко В. В. Нова парадигма вищої освіти в контексті Болонського процесу / В. В. Грубінко, І. І. Бабин // Медична освіта. - 2004. - № 3-4. - С. 7-14.

3. Чабан Т. І. Аналіз об' єктивності тестового контролюзнань студентів вищих медичних навчальних закладів/ Т. І. Чабан, Н. Ю. Ткачишина // Медична освіта. - 2003. -№3. - С. 11-13. зування. Це дало б можливість присвоїти їм статус “друкованих праць”, що, без сумніву, підвищить зацікавленість авторів. В такому разі можна розраховувати на швидкий розвиток подібних інтерактивних технологій в навчанні та, як наслідок, підвищення якості вітчизняної освіти.

Слід також відмітити, щостворення та обслуговування сайту вимагає порівняно невеликих витрат в порівнянні 3 друкуваними підручниками, дисками тощо, що досить важливо в сучасних економічних умовах України.

4. Нейко Є. М. Навчально-методичне забезпечення самостійної роботи студентів при вивченні фундаментальних дисциплін / Є. М. Нейко, Л. В. Глушко, Г. М. Ерстенюк // Медична освіта. - 2004. - № 1. - С. 13-14.

5. Досвід використання сучасних інформаційних технологій в самостійній позааудиторній роботі студентів-медиків / М. І. Яблучанський, С. М. Панчук, О. Ю. Бичкова [та ін.] // / Медична освіта. - 2004. - № 1. - С. 33-34.

6. Історія Вікіпедіï/http://uk.wikipedia.org/w/index.php?title [електронний ресурс]. 